\title{
Hsp90 Inhibitor XL888
}

National Cancer Institute

\section{Source}

National Cancer Institute. Hsp90 Inhibitor XL888. NCI Thesaurus. Code C79835.

An orally bioavailable, AT P-competitive, small-molecule inhibitor of heat shock protein 90 (Hsp90) with potential antineoplastic activity. Hsp90 inhibitor XL888 specifically binds to Hsp90, inhibiting its chaperone function and promoting the proteasomal degradation of oncogenic signaling proteins involved in tumor cell proliferation and survival; inhibition of tumor cell proliferation may result. Hsp90, a chaperone complex protein upregulated in a variety of tumor cell types, regulates the folding and degradation of many oncogenic signaling proteins, including Her-2 and Met. 